\title{
Physicochemical Characteristics and Heavy Metal Levels in Water Samples from Five River Systems in Delta State, Nigeria
}

\author{
${ }^{1 *}$ KAIZER, A.N; ${ }^{2}$ OSAKWE, S.A \\ ${ }^{1}$ Department of Geology, Delta State University, Abraka. Nigeria \\ ${ }^{2}$ Department of Chemistry, Delta State University, Abraka. Nigeria \\ ${ }^{1}$ E-mail:abelkaizer@yahoo.com
}

\begin{abstract}
Physicochemical characteristics and heavy metal levels in water samples from five river systems in central part of Delta State, Nigeria were investigated to access the quality status of the rivers. All the watersheds selected for study were well distributed and possessed similar geology, climate, soil, and vegetation characteristics. Studies on the water samples collected from the rivers showed that the physicochemical characteristics of the river varied significantly. The mean concentration of total solids within the rivers were $35.46 \mathrm{mg} / 1,31.57 \mathrm{mg} / 1,18.82 \mathrm{mg} / 1$ and $45.53 \mathrm{mg} / 1$ for Ase, Agbarho, Ethiope, Ekakpamre and Afiesere rivers respectively. Similarly, the mean concentration of heavy metal in the river system gave the following ranges zinc $0.93-2.96 \mathrm{mg} / 1$, copper $0.01-0.03 \mathrm{mg} / 1$, lead $0.003-0.08 \mathrm{mg} / 1$, cadmium $0.00-0.004 \mathrm{mg} / 1$, chromium $0.001-0.03 \mathrm{mg} / \mathrm{l}$, nickel $0.01-0.004 \mathrm{mg} / 1$, manganese 0.008 $0.04 \mathrm{mg} / \mathrm{l}$, iron $0.03-0.08 \mathrm{mg} / \mathrm{l}$. A comparison of the heavy metal concentration in the respective samples and recommended international standard such as WHO 1993 showed that the rivers were not significantly contaminated and are therefore suitable for domestic and industrial purpose. From the findings, there is need to protect the quality of the water systems for recreational, industrial and domestic uses. It is hoped that the result of this study would help the Delta State government and other interest groups to maintain existing projects, plan and also to execute properly future development programs in the study area. @ JASEM
\end{abstract}

Chemical enrichment in river system are derived through a combined effect of both industrial and municipal effluents and runoffs from surrounding area or through solution effects from adjacent soil. The presence of nutrients in rivers may be attributed to the process of organic mineralization of nitrates and phosphates derived principally from surface runoffs from the immediate vicinity (forests, farms and settlement) and perhaps by insitu minerialization (Ikomi 1997; Kaizer and Adaipkoh 2007; Kaizer and Osakwe 2007). Soil erosion is closely linked with high surface runoffs and rapid siltation of surface water system resulting in subsequent decline in its portability. Eroded materials may exist in river systems as dissolved solids or suspended solids but within a particular regime of flow, river systems bear with them sediments, which constitute the byproducts of processes operating within the environment through which they flow. These are derived though leaching of soil profiles, surface runoffs, direct dumping of wastes (municipal and industry), soil erosion; atmospheric fallouts e.t.c. Heavy metals are toxic and can accumulate in a system without being noticed (Ihenyen 2002). This makes them a source of concern. Sources of heavy metals includes industrial activates (mining, oil exploration activities, manufacturing and agricultural practices), domestics and commercial practices that generates wastes, and natural factors. Metal content in rivers may vary between the water column and bed sediments. However, variation in concentration of parameters depends on concentration from processes operating within the catchments. For the purpose of

\footnotetext{
* Corresponding author: ${ }^{1 *}$ Kaizer, A.N.
}

this study, bed sediments were not considered as part of the sediment load in this study because of the complexity in assessing the actual amount of bed sediments carried along with the water column during each flow regime. This work is therefore aimed at studying the physicochemical characteristics and heavy metal content of the various river systems with a view of accessing the effects of land use on the quality of rivers. It is hoped that the research findings would help in proper assessment of the contaminant status of the various watersheds, aimed towards improving surface water quality within the inland oil producing area of Delta State.

Description of Study Area: The studied watersheds are located in Delta State, Nigeria (longitudes $3^{0} \mathrm{E}-$ $9^{0} \mathrm{E}$ and latitudes $4^{0} 30^{1} \mathrm{~N}-5^{0} 21^{1} \mathrm{~N}$ ) and lies within the southern oil rich Niger Delta region. Five watersheds were selected for study. They include the Ethiope, Agbarho, Ekakpamre, Afiesere and Ase rivers. The watersheds were well distributed and posses similar geology, climates, soil, vegetation and drainage characteristics (Atakpo et al., 2000; Ikomi and Ojieh 1997; Ikomi and Emuh 2000).

\section{MATERIALS AND METHOD}

93 waters samples were collected systematically from five watersheds within the period of 12 months in three sets from January to December. The water samples were collected at an average distance of about $1 \mathrm{~km}$ apart from each watershed. Duplicate samples were collected at each point in chemically clean 1 liter containers each and labeled A and B with 
water sample description detailing the sample condition. All samples labeled A were stabilized by acidifying them with concentrated trioxonitrate $\mathrm{V}$ acid $\left(\mathrm{HNO}_{3}\right)$ to a $\mathrm{pH}$ of 2 . This was done to retard biological action, hydrolysis of some chemical compounds and to reduce volatility of some chemical constitutes. They were stored in ice packed coolers and preserved at a temperature of $4^{0} \mathrm{c}$ before transportation to the laboratory for analysis. This method of preservation was done in order to ensure that no significant changes in composition occurred before the analysis was carried out in the laboratory. All analysis were carried in accordance with international standard methods (APHA 1995) and expressed in $\mathrm{mg} / \mathrm{l}$.

Preparation of Standard Solutions: One gram of the pure metal was dissolved in $20 \mathrm{ml}$ of $\mathrm{HCl}$ and diluted in 1 litre mark of a volumetric flask with de-ionized water to give $100 \mathrm{mg} / \mathrm{l}$ of the metal stock solution. This process was repeated for all metals analyzed. Several solutions of concentrations $4.00 \mathrm{mg} / \mathrm{l}$, $6.00 \mathrm{mg} / \mathrm{l}$ and $8.00 \mathrm{mg} / 1$ were prepared from the stock solution by several dilutions as described by Allen 1974. Heavy metals, analyses were carried out with the aid of the Parkinson absorption spectrometer model 403 using the required lamps.

Results / Discussion: The result of physicochemical analyses carried out on the water samples collected from the selected rivers within the studied area showed various concentrations of the parameters studied in both the oil field area and non oil field area (Table 1). The sediment load was studied based on the Total Solid (TS) concentration obtained through addition of the Total Dissolved Solid (TDS) and Total Suspended Solid (TSS) concentrations for each of the samples. The TS content was mainly due to the dissolved solids with suspended solids present only in small quantities. The result showed that the concentration of the Total Dissolved Solids were greater than the Total Suspended Solid in the samples. Average concentrations of Total Solids in the samples ranged from $18.29 \mathrm{mg} / 1$ in river Ethiope at Abraka to $35.46 \mathrm{mg} / \mathrm{l}$ in Ase Rivers at Ashaka, $45.53 \mathrm{mg} / 1$ in Afiesere River at Ughelli, $31.82 \mathrm{mg} / 1$ in Ekapamre River at Ughelli, $31.57 \mathrm{mg} / 1$ at Agbarho River at Agbarho all in the oil field areas. This low value at Abraka (NOF) reflects the low level of development and mirrors both land and water use effect on the river as compared to other rivers sampled with the highest TDS obtained in the Ase River (NOF). Mean concentration of TDS values recorded were, Ashaka $32.60 \mathrm{mg} / 1$ for, Afiesere(OF) $42.87 \mathrm{mg} / \mathrm{l}$, Ekakpamre(OF) $27.80 \mathrm{mg} / 1$, Agbarho(OF) $30.37 \mathrm{mg} / 1$, and Ehtiope River(NOF) $16.68 \mathrm{mg} / \mathrm{l}$. The observed mean Total Dissolved Solids concentration in the rivers as obtained varied between a minimum of $17.63 \mathrm{mg} / \mathrm{l}$ to a maximum of $42.87 \mathrm{mg} / 1$ with the highest concentration recorded in Afiesere River at Ughelli town. A plot of the concentration of TDS within the studied rivers and conductivity shows that conductivity was directly proportional to the concentration of the TDS. The high conductivity values recorded in Ughelli and Agbarho were probably associated with acidification mainly from the effect of acid deposition from gas flaring and effluent discharged into these receiving water bodies from oil installations within these areas. However, Municipal waste and other industrial waste products contribute also to a lesser extent because of the level of development in these area and poor waste disposal practices. The concentration of the total suspended solids was closely linked to erosion and processes operating within the studied watersheds. The low TSS concentration in the samples analyzed show that the rates of erosion at the watersheds were minimal. However, presence of suspended solids may have been associated with small-scale mining activities such as dredging of sharp sand along the river channels and banks. Generally, all solid content analyzed for, showed concentrations below the World Health Organization (WHO) standards, (1996) for drinking water. Chemical enrichment in river systems were derived through a combined effect of both industrial and municipal effluents and runoffs from surrounding area or through solution effect from adjacent soil. Similarly, the presence of nutrients in the rivers was attributed to the processes of organic mineralization of nitrates and phosphates derived principally from surface runoff from the immediate vicinity (forests, farms and communities) and perhaps by insitu mineralization (Ikomi, 1997). Soil erosion was closely linked with high surface runoffs and rapid siltation of the surface water systems resulting to occasional decline in their portability. The eroded materials exist in the river systems as dissolved solids and/or suspended solids. However, within a particular regime of flow, river systems carry along with them sediments, which constitute the by-product of processes operating within the environment through which they flow. These were derived though leaching of adjourning soil profiles, surface runoffs; direct dumping of wastes (municipal and industrial), soil erosion, atmospheric fallouts etc.

* Corresponding author: ${ }^{1 *}$ Kaizer, A.N. 
TABLE 1: Range and Mean Concentration of Physicochemical Parameters in Studied Rivers

\begin{tabular}{|c|c|c|c|c|c|c|}
\hline Parameters & Ase River & Agbarho River & Ethiope River & Ekakpamre River & Afiesere River & WHO Limits \\
\hline Temperature & $25.99-26.9$ & $25.5-26.35$ & $25.80-26.40$ & $25.48-25.65$ & $26.5-26.8$ & \\
\hline$\left({ }^{0} \mathrm{C}\right)$ & $(26.45 \pm 0.73)$ & $(25.93 \pm 0.55)$ & $(26.10 \pm 0.59)$ & $(25.57 \pm 0.34)$ & $(26.65 \pm 0.21)$ & 1993 \\
\hline Conductivity & $65.5-68.6$ & $42.53-53.60$ & $27.40-35.64$ & $62.51-63.8$ & $73.8-78.2$ & \\
\hline (microohm/cm) & $(67.55 \pm 3.48)$ & $(52.78 \pm 2.93)$ & $(31.52 \pm 0.81)$ & $(63.01 \pm 1.73)$ & $(75.00 \pm 1.73)$ & \\
\hline $\mathrm{pH}$ & 5.93-6.20 & $5.62-5.84$ & $5.57-6.42$ & $5.55-6.25$ & $5.22-6.15$ & \\
\hline & $(6.07 \pm 0.17)$ & $(5.73 \pm 0.39)$ & $(6.39 \pm 0.25)$ & $(5.26 \pm 0.14)$ & $(5.71 \pm 0.31)$ & 65.85 \\
\hline Total solids & $32.85-37.25$ & $29.50-39.83$ & $18.65-18.89$ & $29.60-32.03$ & $41.63-48.15$ & 500 \\
\hline $\mathrm{mg} / \mathrm{l}$ & $(35.46 \pm 0.67)$ & $(31.57 \pm 2.96)$ & $(18.69 \pm 0.59)$ & $(31.82 \pm 0.81)$ & $(45.53 \pm 1.65)$ & \\
\hline Total dissolved solid & $21.67-35.06$ & 28.35-38.66 & $17.60-17.76$ & $24.34-30.33$ & $40.13-46.20$ & $<500$ \\
\hline $\mathrm{mg} / \mathrm{l}$ & $(32.60 \pm 2.42)$ & $(30.37 \pm 4.97)$ & $(17.68 \pm 2.60)$ & $(27.80 \pm 1.33)$ & $(42.81 \pm 1.59)$ & \\
\hline $\begin{array}{l}\text { Total suspended solids } \\
\mathrm{mg} / \mathrm{l}\end{array}$ & $\begin{array}{c}1.18-3.19 \\
(2.86 \pm 0.74)\end{array}$ & $\begin{array}{c}1.15-2.17 \\
(1.20 \pm 0.11)\end{array}$ & $\begin{array}{c}1.05-1.13 \\
(1.01 \pm 0.622)\end{array}$ & $\begin{array}{c}1.26-3.70 \\
(3.02 \pm 0.64)\end{array}$ & $\begin{array}{c}2.50-2.80 \\
(2.66 \pm 0.15)\end{array}$ & 5 \\
\hline Silica $\left(\mathrm{S}_{\mathrm{i}} \mathrm{O}_{2}\right)$ & $10.25-11.92$ & $8.37-12.15$ & $8.53-10.71$ & $8.55-9.56$ & $10.39-11.30$ & \\
\hline $\mathrm{mg} / \mathrm{l}$ & $(11.09 \pm 5.40)$ & $(10.26 \pm 0.36)$ & $(9.62 \pm 0.39)$ & $(9.06 \pm 0.37)$ & $(10.85 \pm 0.31)$ & \\
\hline Phosphate $\left(\mathrm{PO}_{4}{ }^{3}\right)$ & $0.71-0.85$ & $0.34-0.41$ & $0.10-0.13$ & $0.49-0.53$ & $0.71-0.90$ & \\
\hline $\mathrm{mg} / \mathrm{l}$ & $(0.78 \pm 0.14)$ & $(0.34 \pm 0.05)$ & $(0.11 \pm 0.036)$ & $(0.51 \pm 0.04)$ & $(0.81 \pm 0.10)$ & \\
\hline Bicarbonate $\left(\mathrm{HCO}_{3}\right)$ & $1.80-2.30$ & $1.52-2.00$ & $1.50-2.35$ & $2.60-3.08$ & $2.10-2.43$ & 100 \\
\hline $\mathrm{mg} / \mathrm{l}$ & $(1.15 \pm 0.27)$ & $(1.00 \pm 0.13)$ & $(1.93 \pm 0.146)$ & $(1.54 \pm 0.09)$ & $(1.22 \pm 0.27)$ & \\
\hline Chloride (C1) & $8.00-10.15$ & $2.02-5.20$ & $2.30-3.31$ & $5.21-8.80$ & $8.19-12.05$ & 200 \\
\hline $\mathrm{mg} / \mathrm{l}$ & $(6.48 \pm 0.03)$ & $(3.11 \pm 0.11)$ & $(2.81 \pm 0.22)$ & $(4.85 \pm 0.51)$ & $(10.12 \pm 0.03)$ & \\
\hline Sulphate $\left(\mathrm{SO}_{4}^{2}\right)$ & $0.55-0.67$ & $0.44-0.56$ & $0.31-0.44$ & $0.30-0.43$ & $1.35-1.87$ & 200 \\
\hline $\mathrm{mg} / 1$ & $(0.61 \pm 0.17)$ & $(0.53 \pm 0.05)$ & $(0.35 \pm 0.056)$ & $(1.08 \pm 0.69)$ & $(1.64 \pm 0.04)$ & \\
\hline Nitrate $\left(\mathrm{NO}_{3}\right)$ & $0.25-0.60$ & $0.33-0.57$ & $0.48-0.73$ & $0.64-0.73$ & $0.59-1.02$ & 50 \\
\hline $\mathrm{mg} / \mathrm{l}$ & $(1.43 \pm 0.14)$ & $(1.45 \pm 0.26)$ & $(0.61 \pm 0.07)$ & $(3.88 \pm 0.39)$ & $(1.81 \pm 0.07)$ & \\
\hline
\end{tabular}

TABLE 2: Range and Mean Concentration of Metal Levels in Studied Rivers

\begin{tabular}{|c|c|c|c|c|c|c|}
\hline Parameters & Ase River & Agbarho River & Ethiope River & Ekakpamre River & Afiesere River & WHO Limits \\
\hline Calcium $(\mathrm{Ca})$ & $2.05-3.08$ & $2.33-3.11$ & 5.01-5.15 & $4.80-4.90$ & $8.99-4.15$ & 75 \\
\hline$(\mathrm{mg} / \mathrm{l})$ & $(2.57 \pm 0.19)$ & $(1.60 \pm 0.34)$ & $(5.53 \pm 0.30)$ & $(3.48 \pm 0.35)$ & $(4.02 \pm 0.07)$ & \\
\hline $\begin{array}{l}\text { Magnesium }(\mathrm{Mg}) \\
\mathrm{mg} / \mathrm{l}\end{array}$ & $\begin{array}{c}3.20-3.35 \\
(3.28 \pm 0.21)\end{array}$ & $\begin{array}{c}1.55-1.65 \\
(1.60 \pm 0.34)\end{array}$ & $\begin{array}{c}1.70-1.85 \\
(1.78 \pm 0.10)\end{array}$ & $\begin{array}{c}0.92-1.21 \\
(1.08 \pm 0.69)\end{array}$ & $\begin{array}{c}2.51-2.95 \\
(2.73 \pm 0.07)\end{array}$ & 50 \\
\hline $\begin{array}{l}\text { Sodium (Na) } \\
\mathrm{mg} / 1\end{array}$ & $\begin{array}{c}4.75-5.32 \\
(5.04 \pm 0.26)\end{array}$ & $\begin{array}{c}4.62-4.75 \\
(4.69 \pm 0.21)\end{array}$ & $\begin{array}{c}5.11-5.15 \\
(5.13 \pm 0.31)\end{array}$ & $\begin{array}{c}3.80-3.95 \\
(3.88 \pm 0.39)\end{array}$ & $\begin{array}{c}4.11-4.15 \\
(4.13 \pm 0.26)\end{array}$ & 200 \\
\hline $\begin{array}{l}\text { Potassium }(\mathrm{K}) \\
\mathrm{mg} / \mathrm{l}\end{array}$ & $\begin{array}{c}4.43-5.25 \\
(4.84 \pm 0.15)\end{array}$ & $\begin{array}{c}2.22-4.10 \\
(3.61 \pm 0.67)\end{array}$ & $\begin{array}{c}4.19-5.11 \\
(4.75 \pm 0.35)\end{array}$ & $\begin{array}{c}3.45-3.90 \\
(3.48 \pm 0.35)\end{array}$ & $\begin{array}{l}4.71-5.82 \\
(4.77 \pm 0.21)\end{array}$ & 10 \\
\hline $\begin{array}{l}\text { Zinc (Zn) } \\
\mathrm{mg} / \mathrm{l}\end{array}$ & $\begin{array}{c}1.78-2.15 \\
(1.99 \pm 0.01)\end{array}$ & $\begin{array}{c}2.35-3.05 \\
(2.70 \pm 0.28)\end{array}$ & $\begin{array}{c}0.85-1.01 \\
(0.93 \pm 0.19)\end{array}$ & $\begin{array}{c}0.98-1.80 \\
(1.39 \pm 0.21)\end{array}$ & $\begin{array}{c}2.91-3.05 \\
(2.96 \pm 0.44)\end{array}$ & 5 \\
\hline $\begin{array}{l}\text { Copper }(\mathrm{Cu}) \\
\mathrm{mg} / \mathrm{l}\end{array}$ & $\begin{array}{c}0.002-0.003 \\
(0.002 \pm 0.0007)\end{array}$ & $\begin{array}{c}0.001-0.002 \\
(0.01 \pm 0.005)\end{array}$ & $\begin{array}{l}0.001-0.002 \\
(0.01 \pm 0.012)\end{array}$ & $\begin{array}{c}0.001-0.003 \\
(0.02 \pm 0.006)\end{array}$ & $\begin{array}{l}0.003-0.006 \\
(0.03 \pm 0.01)\end{array}$ & 0.05 \\
\hline $\begin{array}{l}\text { Lead (Pd) } \\
\mathrm{mg} / 1\end{array}$ & $\begin{array}{c}0.002-0.005 \\
(0.003 \pm 0.0006)\end{array}$ & $\begin{array}{c}0.002-0.003 \\
0.002 \pm 0.005)\end{array}$ & $\begin{array}{c}0.001-0.002 \\
(0.001 \pm 0.0015)\end{array}$ & $\begin{array}{c}0.007-0.009 \\
(0.008 \pm 0.0036)\end{array}$ & $\begin{array}{c}0.002-0.003 \\
(0.002 \pm 0.001)\end{array}$ & 0.01 \\
\hline $\begin{array}{l}\text { Cadmium }(\mathrm{Cd}) \\
\mathrm{mg} / \mathrm{l}\end{array}$ & $\begin{array}{l}0.001-0.003 \\
(0.001 \pm 0.007)\end{array}$ & $\begin{array}{c}0.001-0.002 \\
(0.001 \pm 0.0007)\end{array}$ & $\begin{array}{c}\mathrm{ND}-<0.001 \\
(\mathrm{ND} \pm \mathrm{ND})\end{array}$ & $\begin{array}{c}0.003-0.005 \\
(0.004 \pm 0.001)\end{array}$ & $\begin{array}{c}0.002-0.003 \\
(0.001 \pm 0.0006)\end{array}$ & 0.05 \\
\hline $\begin{array}{l}\text { Chromium (Cr) } \\
\mathrm{mg} / \mathrm{l}\end{array}$ & $\begin{array}{l}0.001-0.003 \\
(0.002 \pm 0.001)\end{array}$ & $\begin{array}{l}0.001-0.002 \\
(0.001 \pm 0.0007)\end{array}$ & $\begin{array}{c}0.001-0.002 \\
(0.001 \pm 0.0006)\end{array}$ & $\begin{array}{c}0.002-0.006 \\
(0.003 \pm 0.001)\end{array}$ & $\begin{array}{c}0.001-0.002 \\
(0.002 \pm 0.0006)\end{array}$ & 0.05 \\
\hline $\begin{array}{l}\text { Total Iron }(\mathrm{Fe}) \\
\mathrm{mg} / \mathrm{l}\end{array}$ & $\begin{array}{c}0.006-0.011 \\
(0.008 \pm 0.001)\end{array}$ & $\begin{array}{c}0.002-0.007 \\
(0.005 \pm 0.03)\end{array}$ & $\begin{array}{c}0.002-0.003 \\
(0.0021 \pm 0.0006)\end{array}$ & $\begin{array}{c}0.005-0.008 \\
(0.006 \pm 0.01)\end{array}$ & $\begin{array}{c}0.005-0.007 \\
(0.005 \pm 0.0006)\end{array}$ & 0.03 \\
\hline $\begin{array}{l}\text { Nickel (Ni) } \\
\mathrm{mg} / \mathrm{l}\end{array}$ & $\begin{array}{c}0.002-0.004 \\
(0.002 \pm 0.0006)\end{array}$ & $\begin{array}{c}0.002-0.003 \\
(0.002 \pm 0.005)\end{array}$ & $\begin{array}{c}-<0.001 \\
(<0.001 \pm 0.0006)\end{array}$ & $\begin{array}{c}0.003-0.004 \\
(0.003 \pm 0.002)\end{array}$ & $\begin{array}{c}0.002-0.003 \\
(0.002 \pm 0.003)\end{array}$ & 0.05 \\
\hline $\begin{array}{l}\text { Manganese (Mn) } \\
\mathrm{mg} / 1\end{array}$ & $\begin{array}{c}0.02-0.03 \\
(0.02 \pm 0.007)\end{array}$ & $\begin{array}{c}0.02-0.04 \\
(0.02 \pm 0.005)\end{array}$ & $\begin{array}{l}<0.001 \\
(<0.001)\end{array}$ & $\begin{array}{c}0.03-0.04 \\
(0.04 \pm 0.0115)\end{array}$ & $\begin{array}{c}0.02-0.03 \\
(0.03 \pm 0.002)\end{array}$ & 0.05 \\
\hline
\end{tabular}

$\mathrm{ND}=$ Not Detected

Mean Sulphate and Nitrate ions in the five rivers systems studied ranged from $0.35-0.64 \mathrm{mg} / 1$ and $0.43-$ $0.081 \mathrm{mg} / 1$ respectively. These values did not exceed drinking water standard in any of the rivers sampled. $\mathrm{pH}$ in the rivers indicated a slightly acidic water with mean values of 5.71-6.07. The Total Dissolved Solid (TDS) and Total Suspended solids showed low values, ranging between 17.05-42.81 and 0.01$3.02 \mathrm{~m} / 1$ respectively. Similarly a low alkalinity was recorded with mean concentration of $\mathrm{HCO}_{3}{ }^{-}$ions between $1.00-1.93 \mathrm{mg} / \mathrm{l}$. Potassium, Sodium and Calcium showed mean concentrations ranging from $\mathrm{K}^{+} 3.48-4.84 \mathrm{mg} / \mathrm{l} ; \mathrm{Na}^{+} 3.88-5.13 \mathrm{mg} / 1 ; \mathrm{Ca}^{2+} 2.57-$ $5.53 \mathrm{mg} / \mathrm{l}$ respectively among others. Water quality in the river systems was accessed based on the hydrologic balance of the watersheds. This balance was a function of the geology and chemistry of all the tributaries adding to the total volume of the river at

* Corresponding author: ${ }^{1 *}$ Kaizer, A.N. 
the sampled point. The level of acidity on the other hand was studied and found to be controlled by the amount of bicarbonate ions released from carbonates or made available as buffers to the acid radicals and relating the effectiveness of the watersheds to the concentration of $\mathrm{Ca}^{2+}$ present. The result shows a general dominance of chloride, calcium, magnesium and sodium ions in the water. Although all the parameters recorded showed concentration, below the WHO standard recommended for drinking water, it was observed that samples collected from areas close to oil installations such as flow stations showed higher levels of acidity. This increase in acidity was further collaborated by the $\mathrm{SO}_{4}{ }^{2-}$ and $\mathrm{NO}_{3}{ }^{-}$content in the water samples taken from those areas. Within areas of such installations, the flared gas associated with production processes concentrated acid radicals mainly $\mathrm{SO}_{4}{ }^{2-}$ and $\mathrm{NO}_{3}{ }^{-}$in the sensitive noncarbonated, essentially sedimentary deposits (soil). The process of leaching in these soil and contribution from runoff increases the acidity of the water in such areas. Although, all the surface water studied met the WHO standard for drinking water quality and protection of aquatic life, a major contributor to acidity was gas flaring with urban and agricultural land use contributing to a lesser extent. In most cases, the acidity was increased by the low velocities of the streams and high organic input (especially in the oil field areas) from the adjoining lands along with various chemicals discharged into them.

Relative to other rivers studied, elevated concentration of zinc, lead, copper, iron, nickel, manganese and chromium were found in the Afiesere (OF) and Ekapamre (OF) rivers situated near Ughelli - a major oil field community. Generally, metal concentration in river Ethiope (NOF) was smaller in magnitude unlike areas with high population and commercial activities. Concentrations of heavy metals in the rivers were in the order Afiesere (OF) $>$ Ekakpamre (OF) > Ase (NOF) > Agbarho (OF) > Ethiope (NOF). A further comparison of the heavy metal concentrations in the river systems studied with water quality standards and guidelines for drinking water developed by the World Health Organization standard (1993) shows that metal concentrations in the waters were generally low (Table 2). However, there are indications of increasing stress conditions due to occurrence of this metal in the rivers. In terms of the WHO standard (1993) and the tentative limits for toxic substances in drinking water, the studied watersheds are not significantly impacted. The presence of metals can be attributed to anthropogenic activities such as the combustion of fuel by oil installations and automobiles, petrochemical industries, the glass factory and other product industries. Mining as well as other domestic activities contributes to heavy metal concentration and * Corresponding author: ${ }^{1 *}$ Kaizer, A.N. sediment load within an environment. This is the case with the Ashaka and Ughelli rivers where oil exploratory activities have led to flaring of huge volume of gases daily, oil spill, landscaping and site preparations etc as compared to Abraka where such operations are still very low and remote. The rivers studied vary widely in composition and different concentration of TDS prevails. The waters are generally fresh with slightly acidic $\mathrm{pH}$ conditions. Although the presence of nitrate in the samples indicates varying degrees of pollution, principal cations include calcium, sodium, and potassium while the principal anions were bicarbonates and chlorides. Sulphate occurred only in small quantities. Generally, the sediment load in the rivers varied significantly due to observed differences in the nature and degree of activities within the catchments, which is expressed as variation in the amount of sediment present and concentration of the heavy metal in the water sample. Comparing the heavy metal concentrations within the samples and recommended international standards such as WHO 1993 showed that the rivers were not significantly contaminated and therefore suitable for both domestic and industrial purposes. The variation in sediment load among the river system studied signifies that the nature and level of activities also varied between study points. This is reflected such that areas with high activities had the highest concentrations of most parameters. Within the watersheds, impact was accessed in an increased order of Ethiope $<$ Agbarho $<$ Ase $<$ Ekakpamre $<$ Afiesere. The concentration of studied parameters fell within the approved limits set by WHO. However, a gradual increase in parameter concentration with time would pose a serious threat to the lives of the people and the ecosystem in general.

Conclusion: The rivers had very low suspended sediments concentration and relatively high stream discharge, attributed possibly to the physiography of the stream, whose sinuosity and drainage density were high. Major factors that led to the low suspended sediment concentration and relatively high stream discharge include; low erosion rates, rocks/soil type, human activities within the catchments and high low of station of the river channel. The results obtained from the analysis showed that the suspended sediments concentration reached its peak before the stream discharged. Analysis of the result also showed that the suspended sediment discharge was proportional to the stream discharge. Although the suspended sediment concentration reaches its peak before the stream discharge, there was a relationship between both parameters. As the stream discharge increases there was corresponding increase in the suspended 
sediment concentration until it reaches its peak. Thus, the amount of suspended concentration in the sediment delivered to the stream during storm, and the stream discharge was proportion to the sediment discharge directly.

The variations of sediment load in the water column of the systems studied signify that the nature and level also varies between study points. This is reflected in the result of analysis such that areas with high activities reflected highest concentration of most parameters. Within the watersheds, impact was accessed in an increased order Ethiope $<$ Agbarho $<$ Ase $<$ Ekakpemre $<$ Afiese3re. The concentration of studied parameters fell within the approved limits set by WHO. However, a gradual increase in parameters concentration with time would pose a serious threat to the lives of people and ecosystem in general. It is therefore recommended that good environment friendly practice be encouraged in all aspects of operation to include, erosion control practice.

\section{REFERENCES}

Akpoborie, I E; Ekakite, O A; Adaikpoh, E O (2000). The Quality of Groundwater from Wells in part of the Western Niger Delta. J. of NAFAK 5. 7279

American Public Health Association (1995): Standard Methods for the examination of water and wastewater. APH/AWWA/WPCF. Washington D.C., 946 p.

Atakpo, E; Chukwudebelu, J U(1997). Stratigraphic Cross Section of Afiesere area, Deduced from a 2 D migrated section. Bull. Sci. Assoc. of Nig. 21. 133-143.

Ihenyen, A E and Aghimien, A E (2002). A study of trace heavy metal levels in Warri Soils and Vegetables, Southern Nigeria. Afric. J. Environ.Pollut. Health I (1), 72-82.
Ikomi, R B and Ojieh, C N (1997). Some Aspect of the Biology of Aphyosemion gardneri (PISCES: CYPRIODONTIDAE) in River Ethiope, Niger Delta, Nigeria. J. Bioscience Research, 9, 3. 173-181.

Ikomi, R B and Emuh, C T (2000). Studies of the status of the Physico-chemical Hydrology of Upper Warri River, Niger Delta, Nigeria. J. Sci. Environ. 2, 75-86.

Kaizer, A N and Adaikpoh, E O (2006). Some geotechnical properties of soils from Umutu and environ, Southwest Nigeria. J. Appl. Sci. and Environ. Manage. 10 (4), 41-45.

Kaizer, A N and Osakwe, S A (2007). Water chemistry in the Upper and middle Ethiope River, Southwestern Nigeria. J. Sci. and Environ. 6, 147-159.

Kaizer, A N and Adaikpoh, E O (2007). Trace Metal Levels in Surfacewater and Soils within Afiesere oil field area, Southwestern Nigeria. J. Sci. Environ. 6, 1-9.

Kogbe, C A (1989). Geology of Nigeria. Rock View Ltd, $2^{\text {nd }}$ Edition . 311-325.

Oteze, G E (1981). Water Resources of Nigeria. J.Environ. Geol. 3. 171-184.

Reijers, T J (1996). Selected chapters on Geology, Niger Delta Basin. Shell Petroleum Development Company. 197p.

WHO, (1996). International standard for potable Drinking water. Geneva. 